\title{
Expressions of domestic violence against adolescents: Educators' speeches
}

\author{
Expressões da violência doméstica contra adolescentes: discursos de educadoras \\ Expresiones de violencia doméstica contra adolescentes: Discursos del educador
}

Kátia Cordélia Cunha Cordeiro' ORCID: 0000-0003-1850-8999

Nadirlene Pereira Gomes' ORCID: 0000-0002-6043-3997

Luana Moura Campos' ORCID: 0000-0001-5671-1977

Jéssica Damasceno de Santana' ORCID: 0000-0001-9668-3122

Rosana Santos Mota' ORCID: 0000-0002-3193-9972

Climene Laura de Camargo' ORCID: 0000-0002-4880-3916

'Universidade Federal da Bahia. Salvador, Bahia, Brazil.

How to cite this article: Cordeiro KCC, Gomes NP, Campos LM, Santana JD, Mota RS, Camargo CL. Expressions of Domestic Violence Against Adolescents: Educators' Speeches. Rev Bras Enferm. 2020;73(3):e20180656. doi: http://dx.doi.org/10.1590/0034-7167-2018-0656

Corresponding author: Nadirlene Pereira Gomes nadirlenegomes@hotmail.com

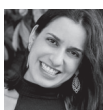

EDITOR IN CHIEF: Dulce Aparecida Barbosa ASSOCIATE EDITOR: Alexandre Balsanelli

Submission: 08-29-2018 Approval: 10-16-2018

\section{ABSTRACT}

Objectives: to describe the expressions recognized by domestic violence educators experienced by school adolescents. Methods: it is a qualitative study based on Paulo Freire's liberating pedagogy. Semi-structured interviews were conducted with 20 teachers from a public elementary school in the city of Salvador, state of Bahia, Brazil. The data were systematized through the Discourse of the Collective Subject. Results: collective discourse reveals that educators identify schoolchildren who experience physical, psychological and negligent abuse, being denied even love and affection. Conclusions: although not alluding to sexual abuse, educators recognize that students are inserted in the context of domestic violence, knowledge necessary for the development of actions that enable the exit of the student from the oppressed and overcoming the lived experience.

Descriptors: Domestic Violence; Adolescent; School Teachers; Education, Primary and Secondary; Nursing.

\section{RESUMO}

Objetivos: descrever as expressões reconhecidas por educadoras da violência doméstica vivenciada por adolescentes escolares. Métodos: trata-se deum estudo qualitativo, fundamentado na pedagogia libertadora de Paulo Freire. Realizaram-se entrevistas semiestruturadas com 20 professoras de uma escola pública de ensino fundamental em Salvador, Bahia, Brasil. Os dados foram sistematizados por meio do Discurso do Sujeito Coletivo. Resultados: o discurso coletivo revela que as educadoras identificam escolares que experienciam abusos físicos, psicológicos e por negligência, Ihes sendo negado inclusive amor e afeto. Conclusões: embora haja não alusão a abusos sexuais, as educadoras reconhecem que os escolares se encontram inseridos no contexto da violência doméstica, saber necessário para o desenvolvimento de ações que viabilizem a saída do educando da condição de oprimido e superação do vivido.

Descritores: Violência Doméstica; Adolescente; Professores Escolares; Ensino Fundamental e Médio; Enfermagem.

\section{RESUMEN}

Objetivos: describir las expresiones, reconocidas por los educadores, de la violencia doméstica experimentada por los adolescentes escolares. Métodos: este es un estudio cualitativo, basado en la pedagogía liberadora de Paulo Freire. Se realizaron entrevistas semiestructuradas con 20 maestros de una escuela primaria pública en el cuidad de Salvador, estado de Bahía, Brasil. Los datos se sistematizaron a través del Discurso del sujeto colectivo. Resultados: el discurso colectivo revela que los educadores identifican a los estudiantes que experimentan abuso físico, psicológico y negligente, negándose incluso el amor y el afecto. Conclusiones: aunque no aluden al abuso sexual, los educadores reconocen que los estudiantes están insertos en el contexto de la violencia doméstica, conocimiento necesario para el desarrollo de acciones que permitan la salida del estudiante de la condición oprimida y la superación de lo vivido. Descriptores: Violencia Doméstica; Adolescente Maestros de Escuela; Educación Primaria y Secundaria; Enfermería. 


\section{INTRODUCTION}

Domestic violence is a public health problem that affects the physical, mental health and school performance of children and adolescents, and may even lead to their deaths. The transformation of this reality requires professional preparation to recognize the reality of oppression experienced by children and youth.

International and national data reveal evidence of oppression in children and adolescents from the expressive rates of domestic violence, mainly in their own homes. An epidemiological study conducted in Taiwan with 355 patients under the age of 18 admitted to the Intensive Care Unit for maltreatment showed a death rate of $9.86 \% \%^{(1)}$. A study on estimates of experiences of violence by children and adolescents revealed that at least $64 \%$ of this audience experienced this disorder in Asia; $56 \%$ in the United States; $50 \%$ in Africa; $34 \%$ in Latin America; $12 \%$ in Europe of children and adolescents who experienced violence ${ }^{(2)}$. A survey in Haiti showed that $67.0 \%$ of the $2,91613-24$ year-olds were regularly subjected to violent discipline, being assaulted by their parents or teachers ${ }^{(3)}$. In Brazil, the Notifiable Diseases Information System (SINAN - Sistema de Informação de Agravos de Notificação) registered 39,281 cases of violence for children and adolescents, with residence being the predominant location in all age groups ${ }^{(4)}$.

Given these indices, it is worth pointing out how much domestic violence impacts the health and life of affected people. Evidence predominantly mentions bodily injuries and emotional disorders such as post-traumatic stress disorder, anxiety and even depressive symptoms $s^{(5-6)}$, besides being more likely to have concentration difficulties and poor school performance. A study conducted in India, Bangladesh and Nepal, South Asian regions, showed that the experience of violence causes mental and physical illness ${ }^{(7)}$. Such repercussions compromise their entire child and youth development, especially regarding educational progress and the achievement of a better quality of life ${ }^{(8)}$, a reality that places adolescents in a position of oppression in the face of a society that silences the underprivileged ${ }^{(9)}$.

Although the consequences in school and health, professionals, especially nursing, have not recognized the problem. Corroborating, a study with health professionals who provided care to children and adolescents experiencing domestic violence showed that most interviewees neglect the situation, not doing any intervention, because they believe this is a family responsibility ${ }^{(10)}$. This is the circumstance that demonstrates the non-implication of professionals in situations like these and ends up reinforcing the oppression of this group ${ }^{(9)}$. A survey of teachers in Turkey's public schools also revealed difficulties for educators in recognizing violence ${ }^{(11)}$. Such difficulties may be related to the lack of professional preparation, fundamental for the recognition of the injury.

Considering that educators are closer to students and that from the interaction with them, they can overcome experience and realities lived and/or culturally learned ${ }^{(9)}$, the study assumes that the bond they establish with students favors the identification of the experience of domestic violence.

\section{OBJECTIVES}

To describe the expressions recognized by domestic violence educators experienced by school adolescents.

\section{METHODS}

\section{Ethical aspects}

All educators were informed about the purpose of the study and the ethical principles that guide it, described in Resolution 466/2012 of the Brazilian National Health Board (Conselho Nacional de Saúde) and signed the Informed Consent Form (ICF). It is noteworthy that this research was approved by the Research Ethics Committee (REC) of the Universidade Fedral da Bahia (UFBA)'s School of Nursing.

\section{Theoretical-methodological framework}

The research used the theoretical framework proposed by Paulo Freire, which defends education as a strategy of transformation of reality, through which it is possible to intervene in collective life, either for the maintenance or overcoming of the lived ${ }^{(9)}$.

\section{Type of study}

This is a qualitative study, linked to the matrix Project called "Universidade e escola pública: buscando estratégias para enfrentar os fatores que interferem no processo ensino/aprendizagem". Bahia State Research Support Foundation (FAPESB - Fundação de Amparo à Pesquisa do Estado da Bahia) funded this study.

\section{Methodological procedures}

\section{Study setting}

The setting was a public school located in a peripheral neighborhood of Salvador, Bahia, Brazil. This school offers education to adolescents from $6^{\text {th }}$ to $9^{\text {th }}$ grade of elementary school, with the majority $(53.97 \%)$ of male students, which led us to adopt expressions related to male students throughout the study. Rapprochement with the school was made possible through extension actions provided for in the parent project, focusing on the thematic axes: alcohol/drug use/abuse, sexuality, bullying and domestic violence. The actions were developed from 2013 to 2017 in partnership with the component Action Curriculum in Community and Society (ACCS - Ação Curricular em Comunidade e em Sociedade) entitled "Abordagem interdisciplinar e transdisciplinar dos problemas de saúde relacionados à violência", which is part of the curricular structure of undergraduate courses. UFBA and has the participation of students from various areas of knowledge.

\section{Data source}

The collaborators were 20 teachers, who met the following inclusion criteria: to be a permanent teacher of the staff of at least six months of work in that school. We excluded a professional after two unsuccessful contact attempts.

\section{Collection, organization and analysis of data}

As data collection technique, the interview was used, guided by a semi-structured form containing aspects related to the 
characterization of the collaborators and the following guiding question: what expressions of domestic violence have you identified in school teens? The interviews were conducted individually between August and September 2017 and had an average duration of 15 to 20 minutes. They occurred in a place agreed with the collaborator, but reserved in order to guarantee the privacy of the same and the confidentiality of the information, being used as codenames the letter "E" of educator and a number representing the order of transcription of the material.

The speeches were recorded, transcribed and systematized through the Discourse of the Collective Subject (DCS). The methodology of the DCS was based on the analysis of statements, which are part of the corpus, from which the core ideas $(\mathrm{Cl})$ or anchorages (AC) were derived from the key expressions (KE) to which they refer. KEs were grouped by similarity of senses into a single synthesis statement. At first, the discourse was analyzed in its literality making it possible to dialogue with the corpus. The interpretation of the data was supported by Paulo Freire's theoretical framework.

\section{RESULTS}

In order to characterize the collaborators, first we will present the sociodemographic aspects, followed by the categories related to the expressions of domestic violence in students identified by these professionals.

Most of the interviewees were women (70\%), which led us to adopt the expressions related to female collaborators. Therefore, where the terms "educators" were displayed, it must be understood that we are alluding to educators and educators.

The sample consisted entirely of teachers with complete higher education and almost all with specialization (90\%). When asked about knowledge about violence, just over half (55\%) reported that this object was not addressed in undergraduate studies, although most (90\%) worked with the theme during their specialization.

In order to integrate the collective thinking of educators about the expressions of domestic violence identified in schoolchildren, the study revealed the following categories: physical; psychological; and by negligence.

\section{Core idea 1: physical}

Collective discourse showed that physical violence is one of the expressions of domestic violence identified by educators. They also indicated that there was a limit of acceptability to the aggressions committed by the family members of students, often practiced in the public space, such as the school.

Violence comes in many forms and the main one is physical. I have known cases of students who suffered physical abuse from their parents beyond the limit. [...] when the child or adolescent crosses the line, usually the parent, grandmother, aunt or older brother react aggressively. They really spankyou, by spanking, with a belt, sandal or spanking! Once, a student had a purple face, when l asked what had happened, he told me that his mother had spanked him. [...] on another occasion, the school called the parents of a boy who had fought with a colleague in the classroom. After the conversation with the director, the mother hit the adolescent in the courtyard in front of everyone.

\section{Core idea 2: psychological}

The statements showed that in their work process, educators have been recognizing the psychological violence experienced by adolescents in their family relationships. Among the expressions, humiliation and verbal aggression were identified, in the form of insults.

I have repeatedly seen one of my students suffering parental violence. [...] I witnessed my own family refer to the adolescent cursing. He with his head down and his mother saying a lot of things. So if you did it in front of me, imagine what you don't do at home? I've heard a student's mother say in the hallway: Why doesn't this misery die? Once a student ran away from home because he could not stand his brother to humiliate and verbally assault him with rude words because he did not accept his sexual orientation. Another time, one of students commented that his grandmother humiliated him so much that he said it would have been better if he had been spanked.

\section{Core idea 3: neglect}

The teachers also identified situations of neglect in the family setting to which students were exposed, such as deprivation of basic rights, such as providing food, housing and also maternal or paternal affection. The speech also reveals the parents' inattention regarding educational follow-up of their children and the abandonment of incapable, which occurred when the adolescent was thrown out of the house.

What I notice a lot here is the family's neglect of them [adolescents]. It is difficult to get parents in school, especially to follow up their children. Two or three students have already told me that they feel overwhelmed by doing housework and that they arrive at school tired, without encouragement and willingness to study. On one occasion we investigated a student who, after assuming homosexuality, was repeatedly absent, and found that his family had him out of the house. He has been abandoned! We had an affair where the father kept his daughter from entering the house. Because of this, she ate at other people's homes and practically lived on the streets. Her parents were called to school and did not attend. Another situation we had was that of a stepfather who did not accept the adolescent and put him out. So he kept roaming the streets.

\section{DISCUSSION}

The discourse revealed that, in the daily interaction with students, educators identify the physical aggression they experience as the main form of expression of domestic violence. This understanding was also found in a study with students and education professionals, besides being shared by professionals from other areas, such as health professionals, such as nurses and other professionals from the minimum team of the Family Health Strategy (FHS) and the Family Health Support Center (NASF - Núcleo de Apoio a Saúde da Família) recognizing bodily injury as the predominant sign of child abuse (BRINO; SOUZA, $2016)^{(12)}$. Such manifestation occurs through aggressions with belt, sandal or spankings, also evidenced in studies conducted in the United States of America ${ }^{(13)}$. When suffering this type of violence, 
the adolescent usually has physical marks, such as bruises, which, because they are visible, are more easily identified by educators.

Despite the recognition of physical abuse as a form of violence, it is noted that educators believe that there is a permissive threshold for this type of aggression. This is due to the common sense understanding that it is acceptable to use physical aggression against children and adolescents as an educational strategy, a socially shared belief in several countries, such as Turkey ${ }^{(11)}$. An example of this naturalization of physical violence as a form of adolescent punishment was revealed in the study from the educator's report about the public aggression of an adolescent by his mother. In view of this conception, Paulo Freire ${ }^{(9)}$ argues that the modification of a socially constructed thought is feasible. Although people are endowed with a preestablished culture, it can serve as the starting point for the transformation process. Thus, spaces are needed to promote reflection by those responsible for peaceful conflict strategies anchored in the culture of peace and nonviolence, as well as the damage of these abuses to the lives of individuals.

Understanding that there is no way to consider the intensity of the physical aggression perpetrated against children and adolescents, as well as the damage to this population group, Law 13.010/2014, popularly known as "Spanking" Law. It provides that parents, guardians or anyone in charge of caring for subjects under the age of eighteen should be penalized if they use physical punishment, cruel or degrading treatment as a means of correction, discipline, education or for any other reason ${ }^{(14)}$. In other nations, such as New Zealand, physical aggression, as well as all other expressions of violence against children and adolescents, is unacceptable and not even tolerated by any form of verbal aggression such as insults and name calling ${ }^{(15)}$.

Unlike the reality of developed countries like New Zealand, our study exposes a daily school life marked by psychological violence committed by family members of adolescents, expressed through insults. It is necessary to warn that the perpetration of this type of violence in the public environment, as in school, reveals the humiliating and degrading character of this violence, which also makes this place of oppression. This reality contradicts Paulo Freire's pedagogical premises that argues that the school must be a propitious setting for liberation ${ }^{(9)}$.

Experiencing psychological violence has great representativeness for the affected person. This could be identified in the teachers' collective discourse that revealed an occasion when the student expresses the "preference" for physical violence over the humiliations suffered. Thus, given the confrontation between remaining in such a context and distancing themselves from this reality, adolescents may decide to move away from family life, opting for escape from home. Because this is a situation that is not restricted to the adolescent public, and may occur in people's lives earlier, a Colombian ethnographic study that investigated homeless people showed that family-generated child violence in the form of abuse physical, psychological and sexual causes the child to leave home ${ }^{(16)}$.

It is noteworthy that psychological violence is not only responsible for the removal of the adolescent from the family, and it is possible to expel them from their homes by their own responsible, which is configured as neglect. This form of expression was also perceived in the report of adolescents in a study that pointed to the experience of abandonment ${ }^{(17)}$. It alerts us to the fact that homosexuality has been flagged as a reason for intensifying family conflicts, which culminated in the expulsion of adolescents from their homes and makes us reflect on the greater vulnerability of this public to the experience of the offense.

Like shelter, food security and education are essential for human development. These violations, also revealed in the discourse of educators, lead to negligence regarding the guarantee of basic needs, as in the cases where students who had nothing to eat. Corroborating with our studies, research conducted in the state of Goiás, Brazil, brings reports of educators who perceived hunger and abandonment as forms of violence ${ }^{(18)}$. It is important to emphasize the responsibility of parents in guaranteeing the rights to their children that, when absent, can be configured as material negligence, being responsible for the omission of the fundamental rights of children and adolescents based on art. 5 of the Child and Adolescent Statute (ECA - Estatuto da Criança e do Adolescente) ${ }^{(19)}$.

In addition to food deprivation, the teachers' discourse alluded to neglect, expressed by the lack of affectionate relationship between parents and adolescents. Affective abandonment is understood as a reflection of not caring for children ${ }^{(17)}$. The affection received during childhood and youth are essential care and of fundamental importance in the development of adolescents. Children and adolescents who do not have a positive connection with their family and coexistence based on affection and love, cannot show these feelings to others ${ }^{(20)}$, it is through these feelings that creativity and ease in interpersonal relationships are stimulated.

Family member distancing also extends to the school space, in the form of disinterest in the progress of their daughters studies, referring to the difficulty of school-parent interaction. Although ECA recommends the obligation to enroll daughters in schools, it is not uncommon for parents to be unconcerned about attending classes and/or school development. Linked to this reality is the overload of domestic activities that compromise the quality of students' learning, which leads to the neglect of family members regarding some needs specific to the adolescence phase, as a guarantee of education and leisure ${ }^{(19)}$. However, it can be considered that there is a fine line between understanding domestic work as violence or not, and this threshold is linked to the adolescent's exclusive obligation to perform it. It is a situation that compromises their quality of life, such as the low school performance indicated in the speech.

It is noteworthy that educators did not mention the existence of sexual violence in their speeches. This may be associated with the fact that they do not receive guidance during academic and vocational training to identify signs of this phenomenon ${ }^{(21)}$. Therefore, the professional incapacity to suspect sexual abuse is signaled, predisposing the masking of the problematic and continuing victimization of adolescents.

However, non-reporting of sexual abuse by teachers may also be related to the silencing of the victims. Brazilian study shows that children and adolescents, on average, experience sexual violence about two years until it is revealed ${ }^{(22)}$. This culture of silence, in Freire's perspective, can be broken from the relationship 
of educator-educator proximity, making the adolescent not only discover their possibility of speech, but also realize that their critical discourse about what they lived can be a form of reinventing the world and consequently overcoming the lived.

Thus, there is a need for professional preparation for the process of identifying sexual abuse, whose form of action is not limited to the interview, but is capable of apprehending behaviors that evidence the experience, even if it is not verbalized. A study reveals that, although this dialogue is extremely relevant, the use of techniques that enable the management of emotional and motivational factors that favor the reporting of abuse is essential. Linked to the forensic area, this technique of psychological assessment has been increasingly used in the legal area precisely because it is considered one of the means of proof of the occurrence of crime against children and adolescents ${ }^{(23)}$.

Despite the specificity of the experts to analyze the materiality of the facts, we must not fail to consider the seriousness of suspected sexual abuse situations, since it is from these that the cases are investigated with a view to protecting children and adolescents. At this juncture, educators are in a privileged position given the time of living with students, in addition to the bond of trust often established between them. In Paulo Freire's perspective, the school, in the figure of the teacher, is in a position to be able to make possible from the dialogue the exit of the student from the oppressed condition, considering the understanding about his reality and making him act for his liberation ${ }^{(9)}$. Hence the importance of maintaining this interaction. This educator-learner relationship is addressed in some international studies that demonstrate how student students who experience violence, not just sexual ones, tend to share their experiences with their teachers ${ }^{(24)}$.

Although educators are in a strategic position to identify the offense, it is worth mentioning that the lack of preparation for the suspicion and identification of domestic violence, as well as dealing with the situation, is not restricted to sexual abuse, and the other forms are often unnoticed. A study conducted in Kanpur, Uttar Pradesh and India shows this difficulty in recognizing teachers' domestic violence. Of the 225 respondents, $74.5 \%$ reported never or rarely acknowledging child neglect or abuse, pointing to lack of knowledge, uncertainty and fear as major barriers ${ }^{(25)}$. This points to the need for training spaces that allow praxis, which, according to Paulo Freire ${ }^{(9)}$, concerns reflection on practice. This has the educator as a subject, which reflects his daily life and creates and recreates it, being in constant formation, because the practice is changeable and dynamic.

The importance of professional preparation for acting in situations of domestic violence is not limited to the scope of education. Like educators, research points to limitations, with regard to the identification and care of people in situations of violence, those who work in health spaces, such as nurses and doctors, who assist children and youth in child care settings, emergency care, among others. An American study of 302 pediatric doctors showed that only $4 \%$ of respondents investigated the experience of domestic violence in this group ${ }^{(26)}$. In Ceará, Brazil, a study shows that most doctors reported not having attended domestic violence training at undergraduate level, did not read about the topic in question and did not discuss it in the workplace, and did not know about the file. notifications of violence, nor institutions for assisting victims of abuse ${ }^{(27)}$.

In spite of professional limitations, the repercussions of domestic violence reach health and school spaces either in a veiled or explicit manner. These spaces become unique privileges for identifying the problem, which can be through articulation with FHS professionals, more specifically by the School Health Program (PSE - Programa Saúde na Escola) ${ }^{(28)}$ in partnership with the NASF team. It is important to highlight that the municipalities that join the PSE receive financial support directly from the Federal Government for actions to promote a culture of peace and prevention of violence. In this setting, the performance of the nurse, a key professional in the process of intersectoral articulation, stands out, as they recurrently occupy management spaces in the $\mathrm{FHS}^{(5)}$.

For this, a management with the purpose of professional preparation for the suspicion, identification and notification of the cases, as well as acting with the victims and their families is essential. This need is corroborated by national and international scientific evidence, such as research conducted in Iceland, which emphasized the importance of preparing educators to recognize the violence suffered by their students. The greater proximity between them favors the understanding of family dynamics ${ }^{(29)}$, and a Brazilian study that reinforces the need for investments in the training of health professionals ${ }^{(30)}$. In this sense, the process of ongoing formation is fundamental, which requires continuous assessment of the challenges perceived by educators in daily school life, which function as privileged objects in the formative process in view of their transformation ${ }^{(9)}$.

\section{Study limitations}

Considering that the investigation is limited to a public school in northeastern Brazil, given the socioeconomic and cultural conjuncture of this group, we cannot generalize the findings, although they indicate the importance of professionals to be aware of this problem.

\section{Contributions to nursing, health}

Considering the implications of the experience of intrafamily violence for the quality of life of students, by revealing the expressions of violence recognized by educators, the study contributes to the unveiling of signs that may guide the identification of the experience of this disease by other educators and other professionals who work. with this public, especially in the scope of Primary Health Care. Nurses who are part of the FHS teams and often the coordination positions sand out. It also draws attention for the possibility of articulation between the FHS and public school, in order to favor the recognition of the phenomenon among students and thus decision-making with a view to notification and necessary referrals.

\section{FINAL CONSIDERATIONS}

In the context of interaction with students, the study reveals the situation of oppression experienced by students in the family setting, which is expressed through physical, psychological and negligent 
forms. The recognition of students experiencing domestic violence points to the importance of educators who, in their praxis, pay attention to the collective life, enabling the identification of abuse.

It is noteworthy that educators did not identify sexual violence in daily school life, which may be related to the silence of the victims. This situation demands greater attention for its recognition, which can be made possible through the process of interaction between educator-learner based on a dialogical model that allows the valorization of the adolescent's speech. To this end, it is worth highlighting the articulations with nurses and doctors who work in the FHS and NASF team professionals with a view to promoting spaces. They are guided mainly by active-participatory methodologies, which enable the overcoming of the lived from the liberating educational action.

From the perspective of the critical-transforming praxis of those who work in the school setting, a management available to organize educational proposals that contribute to the identification of domestic violence is essential. Such proposals must transcend content perspectives, rooted in the banking model, since the complexity involved in the experience of domestic violence requires closer approximation between the subjects. Hence the importance of the implementation of the dialogical model in daily school life, which may contribute to the recognition of situations of oppression, an essential condition for transformative practice.

\section{REFERENCES}

1. Lee E-P, Hsia S-H, Huang J-L, Lin J-J, Chan O-W, Lin C-Y, et al. Epidemiology and clinical analysis of critical patients with child maltreatment admitted to the intensive care units. Medicine (Baltimore) [Internet]. 2017[cited 2018 May 12];96(23):e7107. Available from: http://www. ncbi.nlm.nih.gov/pubmed/28591056

2. Hillis S, Mercy J, Amobi A, Kress H. Global prevalence of past-year violence against children: a systematic review and minimum estimates. Pediatrics [Internet]. 2016 [cited 2018 May 12]; 137(3):e20154079. Available from: http://pediatrics.aappublications.org/content/ pediatrics/137/3/e20154079.full.pdf

3. Flynn-O'Brien KT, Rivara FP, Weiss NS, Lea VA, Marcelina LH, Vertefeuille J. Prevalência de violência física contra crianças no Haiti: um estudo transversal de base populacional nacional. Abuso Infantil Negl. 2016 Jan; 51: 154-62. doi: 10.1016/j.chiabu.2015.10.021

4. Waiselfisz JJ. Mapa da violência 2012: crianças e adolescentes do brasil [Internet]. 1a. Flacso Brasil, editor. Rio de janeiro: Marcelo Doher; 2012[cited 2018 May 12]. 84 p. Available from: http://mapadaviolencia.org.br/pdf2012/MapaViolencia2012_Criancas_e_Adolescentes.pdf

5. Magalhães JRF de, Gomes NP, Mota RS, Campos LM, Camargo CL de, Andrade SR de. Intra-family violence: experiences and perceptions of adolescents. Esc Anna NeryRev Enferm [Internet]. 2017 [cited 2018 May 12];21(1). Available from: http://www.gnresearch.org/ doi/10.5935/1414-8145.20170003

6. Rivera LR, Hernández PR, Amezcua BP, Lépez AL, De Castro F. Factores individuales y familiares asociados con sintomatología depresiva en adolescentes de escuelas públicas de México. Salud Publica Mex [Internet]. 2015 [cited 2018 May 12];57(3):219-26. Available from: http:// www.scielo.org.mx/pdf/spm/v57n3/v57n3a10.pdf

7. Ferdousy EZ, Matin MA. Association between intimate partner violence and child morbidity in South Asia. J Heal Popul Nutr [Internet]. 2015 Dec 14 [cited 2018 May 12];33(1):16. Available from: http://www.jhpn.org/content/33/1/16

8. Sherr L, Hensels IS, Skeen S, Tomlinson M, Roberts KJ, Macedo A. Exposure to violence predicts poor educational outcomes in young children in South Africa and Malawi. Int Health [Internet]. 2016[cited 2018 May 12];8(1):36-43. Available from: https://academic.oup.com/ inthealth/article-lookup/doi/10.1093/inthealth/ihv070

9. Freire P. Pedagogia do oprimido: saberes necessários à prática educativa. 41ª ed. Paz e Terra: Rio de Janeiro; 2005.

10. Egry EY, Apostólico MR, Morais TCP, Lisboa CCR. Enfrentar a violência infantil na Atenção Básica: como os profissionais percebem? Rev Bras Enferm [Internet]. 2017 [cited 2018 May 12];70(1):119-25. Available from: http://www.scielo.br/pdf/reben/v70n1/en_0034-7167reben-70-01-0119.pdf

11. Karadag SÇ, Sönmez S, Dereobalı N. An Investigation of Preschool Teachers' Recognition of Possible Child Abuse and Neglect in Izmir, Turkey. J Interpers Violence [Internet]. 2015 Mar 13 [cited 2018 May 12]; 30(5):873-91. Available from: http://www.ncbi.nlm.nih.gov/ pubmed/24928252

12. Massoni ACLT. Maus-tratos na infância e adolescência: conhecimento e atitude de profissionais de saúde. Arq. Odontol. 2014 Jun; 50(2):7177. Available from: https://seer.ufmg.br/index.php/arquivosemodontologia/article/view/2125

13. Taylor CA, AI-Hiyari R, Lee SJ, Priebe A, Guerrero LW, Bales A. Beliefs and ideologies linked with approval of corporal punishment: a content analysis of online comments. Health Educ Res [Internet]. 2016 Aug 1 [cited 2018 May 12];31(4):563-75. Available from: https://academic. oup.com/her/article-lookup/doi/10.1093/her/cyw029

14. Brasil. Lei no 13.010, de 26 de junho de 2014. Altera a Lei no 8.069, de 13 de julho de 1990 (Estatuto da Criança e do Adolescente), para estabelecer o direito da criança e do adolescente de serem educados e cuidados sem o uso de castigos físicos ou de tratamento cruel ou degradante, e altera a Lei no 9.394, de 20 de dezembro de 1996 [Internet]. 2014. [cited 2017 mai 15]. Available from: http://www.planalto. gov.br/ccivil_03/_Ato2011-2014/2014/Lei/L13010.htm.

15. Forbes D. Physical punishment: Sanctioned violence against children. J Paediatr Child Health [Internet]. 2017 May 1 [cited 2018 May 12];53(5):445-6. Available from: http://doi.wiley.com/10.1111/jpc.13530 
16. Sánchez-Suárez D, Giraldo-Puerta A, Giraldo-Pineda Á, Forero-Pulido C. Compartir y desconfiar: mirada de los venteros acerca de los niños en situación de calle. Rev Salud Pública [Internet]. 2016 Jun 27 [cited 2018 May 12];18(3):391. Available from: http://www.ncbi.nlm.nih.gov/ pubmed/28453102

17. Magalhães JRF de, Gomes NP, Campos LM, Camargo CL de, Estrela FM, Couto TM. Expressão da violência intrafamiliar: história oral de adolescentes. Texto Context Enferm [Internet]. 2017[cited 2018 May 12];26(4). Available from: http://www.scielo.br/pdf/tce/v26n4/en_01040707-tce-26-04-e1730016.pdf

18. Pedrosa SM, Gontijo DT, De Souza MM, Silva MAI, Medeiros M. Violence and the school context: meanings for public education teachers. Ciência, Cuid Saúde [Internet]. 2016 Jul 1 [cited 2018 May 12];15(3):397. Available from: http://periodicos.uem.br/ojs/index.php/ CiencCuidSaude/article/view/29815/18277

19. Governo Federal (BR). Lei no 8.069 de 13 de julho de 1990. Dispõe sobre o Estatuto da Criança e do Adolescente e dá outras providências. 1990. [cited 2018 Abr 26]. Available from: http://www.planalto.gov.br/ccivil_03/Leis/L8069.htm

20. Reginatto R. A importância da afetividade no desenvolvimento e na aprendizagem. REI - Rev Educ Ideau [Internet]. 2013 [cited 2018 May 12];8(18):1-12. Available from: https://www.ideau.com.br/getulio/restrito/upload/revistasartigos/11_1.pdf

21. Márquez-Flores MM, Márquez-Hernández VV, Granados-Gámez G. Teachers'knowledge and beliefs about child sexual abuse. J Child Sex Abus [Internet]. 2016 [cited 2018 May 12];25(5):538-55. Available from: http://www.tandfonline.com/doi/full/10.1080/10538712.2016.1189474

22. Magnabosco Marra M, Fortunato Costa L. Caracterização do Abuso Sexual em Clientela do CREAS. Rev Subjetividades [Internet]. 2016 Aug 31 [cited 2018 May 12];16(2):105-16. Available from: http://periodicos.unifor.br/rmes/article/view/5204

23. Gava LL, Pelisoli C, Dell'Aglio DD. Avaliação Psicológica [Internet]. Vol. 12, Avaliação Psicológica. Instituto Brasileiro de Avaliação Psicológica. UFRGS; 2013 [cited 2018 May 12]. 137-45 p. Available from: http://pepsic.bvsalud.org/scielo.php?script=sci_arttext\&pid=S1677-04712013000200005\&lng $=$ pt\&nrm=iso

24. Katz C. "Please believe me; I am the biggest liar that exists": characterising children's recantations during forensic investigations. Child Youth Serv Rev [Internet]. 2014 [cited 2018 May 12];43:160-6. Available from: https://www.sciencedirect.com/science/article/pii/ S0190740914002059

25. Ramesh G, Kumar A, Raj A, Gupta B, Katiyar A, Nagarajappa R. Child abuse and neglect: a survey on primary school teachers of Kanpur city. Int J Med Toxicol Foren Med. 2017;7(2):105-16. Available from: https://www.sid.ir/en/Journal/ViewPaper.aspx?ID=580851

26. Kerker BD, Storfer-Isser A, Szilagyi M, Stein REK, Garner AS, O'Connor KG, et al. Do pediatricians ask about adverse childhood experiences in pediatric primary care? Acad Pediatr [Internet]. 2016[cited 2018 May 12];16(2):154-60. Available from: http://linkinghub.elsevier.com/ retrieve/pii/S1876285915002338

27. Silva Jr GB, Rolim ACA, Moreira GAR, Corrêa CRS, Vieira LJE de S. Identificação e notificação de maus-tratos em crianças e adolescentes por médicos de família no ceará. Trab Educ Saúde [Internet]. 2017[cited 2018 May 12];15(2):469-84. Available from: http://www.scielo.br/pdf/ tes/v15n2/1678-1007-tes-1981-7746-sol00058.pdf

28. Jordan KS, MacKay P, Woods SJ. Child Maltreatment: Optimizing Recognition and Reporting by School Nurses. NASN Sch Nurse [Internet]. 2017[cited 2018 May 12];32(3):192-9. Available from: http://www.ncbi.nlm.nih.gov/pubmed/27927980

29. Gedara NJJH. Domestic violence and children: raising awareness of school personnel responsibilities [Internet]. University of Iceland School of Education; 2016 [cited 2018 May 12]. Available from: https://skemman.is/handle/1946/26240

30. Silveira TB, Netto de Oliveira AM, Algeri S, Susin LRO, Baisch ALM, Marques LA, et al. The invisibility of psychological violence against children. J Hum Growth Dev [Internet]. 2016 Nov 28 [cited 2018 May 12];26(3):345. Available from: http://www.revistas.usp.br/jhgd/article/view/122818 